\title{
Serum Zinc Concentration and Acute Diarrhea in Children from Different Regions of Uzbekistan
}

\author{
Gulnara A. Ibadova*, T. A. Merkushina, E. S. Abdumutalova and Aybek V. Khodiev \\ Infectious and Parasitic Diseases of Children, Tashkent Institute of Postgraduate Medical Education, Tashkent City, Uzbekistan
}

\section{Objective}

To study the blood serum zinc concentration in children with acute diarrhea (AD) in in-patient facilities before and after therapy.

\section{Introduction}

There are several reports of zinc deficiency in pathogenesis of acute and chronic diarrhea. The literature review showed children with diarrhea and chronic gastroduodenitis performed zinc deficiency in majority of cases (1). The normal values of zinc in blood serum are $12.8-27.8 \mu \mathrm{mol} / 1$ (2). There is a threshold of $13 \mu \mathrm{mol} / 1$ zinc concentration for zinc deficiency diagnosis. The zinc level $8.2 \mu \mathrm{mol} / 1$ and below is poor prognostic criteria (3).

\section{Methods}

Totally 102 children (1-14 years old) with AD in in-patient facility from different regions were studied for serum zinc concentration before and after treatment. Termez and Saraosie cities are located in south of Uzbekistan, in the region with high negative impact from the nearly Tajikistan located aluminum producing plant. The serum zinc level measured by neutron-activation method in the Institute of Nuclear Research (INR).

\section{Results}

The zinc concentration in serum significantly varied by the region (Table 1).

The level of zinc in children from Tashkent estimated at lower normal limit with reduction below normal values after treatment. Children from Termez during admission to the in-patient facilities were zinc deficient with further reduction to the poor prognostic level. Children in Saraosie admitted to the in-patient with significant zinc deficiency that remained on poor prognostic level after treatment.

\section{Conclusions}

The study results may indicate the treatment of AD in children do not replenish the zinc to the appropriate level. Though some con- founding factors may contribute the observed zinc disorders the results may indicate environmental factors, such as pollution by aluminum producing plant emission to contribute the difference in zinc concentration and should be considered for the correction and treatment of $\mathrm{AD}$ in children.

Table 1.The serum zinc concentration in children with acute diarrhea from different regions of Uzbekistan before and after treatment.

\begin{tabular}{|c|c|c|c|}
\hline \multirow{2}{*}{ City } & \multirow{2}{*}{} & \multicolumn{2}{|c|}{ Zinc concentration, $\mu$ mol/ $/$ (mean \pm SD) } \\
\cline { 3 - 4 } & & Before treatment & After treatment \\
\hline Tashkent city (capital) & 36 & $13.8 \pm 1.5$ & $12.5 \pm 1.3$ \\
\hline Termez city & 40 & $9.1 \pm 0.08$ & $7.47 \pm 0.01$ \\
\hline Saraosie city & 26 & $7.9 \pm 0.3$ & $7.5 \pm 0.8$ \\
\hline
\end{tabular}

\section{Keywords}

Acute diarrhea; zinc; zinc deficiency

\section{Acknowledgments}

Authors express their gratitude to the staff of Institute of Nuclear Research.

\section{References}

1. Brooks WA, Santosham M, Roy SK, Faruque ASG, Wahed MA, Nahar K, Khan AI, Khan a F, Fuchs GJ, Black RE. Efficacy of zinc in young infants with acute watery diarrhea. [Internet]. The American journal of clinical nutrition 2005 Sep;82(3):605-10.Available from: http://www.ncbi.nlm.nih.gov/pubmed/16155274

2. Ackland ML, Michalczyk A. Zinc deficiency and its inherited disorders -a review. [Internet]. Genes \& nutrition 2006 Mar;1(1):419.Available from: http://www.ncbi.nlm.nih.gov/pubmed/18850219

3. Karlinskiy VM. Zinc deficiency syndrome. Nutrition issues 1980;1:10 18

*Gulnara A. Ibadova

E-mail: prof.lbadova@mail.ru 